\title{
Russian Universities: Problems, COVID-19 \& Efforts
}

\section{Universidades Rusas: Problemas, COVID-19 y Esfuerzos}

DOI: $10.46932 / \mathrm{sfjdv2n3-041}$

Received in: May 1st, 2021

Accepted in: Jun 30th, 2021

\section{Carlos Rios-Campos}

Investigador RENACYT. Doctor en Gestión Universitaria. Maestro en Administración. Ingeniero de Sistemas. Docente de la Universidad Nacional Toribio Rodríguez de Mendoza de Amazonas. Bagua, Perú.

E-mail: carlos.rios@untrm.edu.pe

\section{Shirley Tatiana Bustamante Vilchez}

MSc. en Ingeniería Ambiental y Seguridad Industrial. Estudiante de Doctorado en Ciencias Ambientales. Bióloga. Consultora independiente en temas ambientales. Sullana, Perú.

E-mail: biotabu@hotmail.com

\section{Patricia Mercedes Tapia Macias}

Magíster en Ciencias Internacionales y Diplomacia. Abogada. Guayaquil, Ecuador.

E-mail: patty_tapia56@yahoo.com

\section{Julissa Elizabeth Reyna Gonzalez}

Magister en Educación. Maestra en Administración y Marketing. Candidata a Doctora en Educación. Docente de la Universidad Nacional Hermilio Valdiz Universidad Nacional Hermilio Valdizán. Huánuco, Perú.

E-mail: jreyna@unheval.edu.pe

\section{Freddy Ronald Huapaya Condori}

Ingeniero de Sistemas e Informática de la Universidad de Huánuco - (UDH). Maestro en Gestión de Proyectos. Docente de la Universidad Nacional Hermilio Valdizán. Huánuco-Perú.

E-mail: frerox12@hotmail.com

\section{Irene Merino Flores}

Bachiller en Psicología y Licenciada de la Universidad César Vallejo (UCV). Maestría en Gestión del

Talento Humano. Doctorado concluido en Ciencias Administrativas. Docente de la Universidad Privada Antenor Orrego - (UPAO), Universidad Nacional de Piura, Escuela de Posgrado de la Universidad Cesar Vallejo - Piura, Universidad Católica de Trujillo Benedicto XVI. Perú.

E-mail: imerino@ucvvirtual.edu.pe

\section{Jury Yesenia Aquino Trujillo}

Maestra en Ingeniería de Sistemas. Docente de la Universidad Católica Santo Toribio de Mogrovejo.

Chiclayo, Perú.

E-mail: jaquino@usat.edu.pe

\section{Irma Rumela Aguirre Zaquinaula}

Doctora en Administración de la Educación. Docente Ordinaria Asociada de la Universidad Nacional de Jaén. Jaén, Perú. 
E-mail: irma.aguirre@unj.edu.pe

\begin{abstract}
It is necessary to know the state of the Russian universities. In this paper the general objective was determine the situation of Russian universities: Problems, COVID-19 \& efforts. Methodology, in this research, 41 documents have been selected, carried out in the period 2016 - 2021; including: scientific articles, review articles and information from websites of recognized organizations. The keywords used in the searches were: Russian universities and COVID-19. Results, it was observed the equivalents of the Russian and the United States scale, the documents required at each educational level and the levels of the Russian educational system; the reforms of higher education in Russia were observed, in the period 1991 - 2015, with which it was sought to improve and modernize it. Although, more reforms are pending, especially to successfully face the current pandemic; it was observed that the number of students enrolled in higher education institutions has decreased in the period from 2014/2015 to 2018/2019, due to various causes; it was observed that Lomonosov Moscow State University is the highest university located in the Times Higher Education 2021 ranking. Conclusions, for Russian universities, the number of international students is a great indicator of internationalization. Russian universities need to improve their collaboration with industry. Universities closed in March of 2020, during the pandemic. An important number of universities have provided jobs for students who need help. The most important institution is Lomonosov Moscow State University (MSU). Russian universities are gradually achieving a better position in the world rankings, for this it is important to continue with their process of internationalization and investment in infrastructure.
\end{abstract}

Keywords: Russian universities, COVID-19.

\title{
RESUMEN
}

Es necesario conocer el estado de las universidades rusas. En este trabajo el objetivo general fue determinar la situación de las universidades rusas: Problemas, COVID-19 y esfuerzos. Metodología, en esta investigación se han seleccionado 41 documentos, realizados en el período 2016 - 2021; incluyendo: artículos científicos, artículos de revisión e información de sitios web de organizaciones reconocidas. Las palabras clave utilizadas en las búsquedas fueron: universidades rusas y COVID-19. Resultados, se observó los equivalentes de la escala rusa y estadounidense, los documentos requeridos en cada nivel educativo y los niveles del sistema educativo ruso; Se observaron las reformas de la educación superior en Rusia, en el período 1991 - 2015, con las que se buscó mejorarla y modernizarla. Aunque quedan pendientes más reformas, sobre todo para afrontar con éxito la pandemia actual; se observó que el número de estudiantes matriculados en instituciones de educación superior ha disminuido en el período de 2014/2015 a 2018/2019, por diversas causas; Se observó que la Universidad Estatal de Moscú Lomonosov es la universidad más alta ubicada en el ranking Times Higher Education 2021. Conclusiones, para las universidades rusas, el número de estudiantes internacionales es un gran indicador de internacionalización. Las universidades rusas deben mejorar su colaboración con la industria. Las universidades cerraron en marzo de 2020, durante la pandemia. Un número importante de universidades ha proporcionado trabajo a estudiantes que necesitan ayuda. La institución más importante es la Universidad Estatal de Moscú Lomonosov (MSU). Las universidades rusas están logrando gradualmente una mejor posición en los rankings mundiales, para ello es importante continuar con su proceso de internacionalización e inversión en infraestructura.

Palabras clave: Universidades Rusas, COVID-19. 


\section{INTRODUCTION}

Russian Federation represented $2.0 \%$ of the world population and $2 \%$ of the researchers while accounting to $2.2 \%$ of the world publications (14th place in the world scholarly output) with overall fieldweighted citation impact of 0.75 (Avanesova, Shamliyan, 2018).

Russia has a great number of universities throughout the country - from Kaliningrad to Vladivostok. Some educational centres offer a full range of programmes in various specialities, others are highly specialized, for example, medical or technical universities (Study in Russia, 2021).

There are 50 specially-funded and research-focused National Research Universities and Universities of National Innovation, as well as nine Federal Universities, which were established to bundle regional education and research efforts and focus on regional socioeconomic needs in more remote parts of Russia (Potapova \& Trines, 2017).

The Russian leadership pays focused attention to the ranking positions of our universities, which resulted in the development of the national program "5-100-2020" in 2013, the implementation of which should allow at least five Russian universities to occupy positions in a leading hundred of the QS World University Ranking in 2020 (Rodionov, Fersman \& Kushneva, 2016).

The preeminent institution is Lomonosov Moscow State University (MSU), firmly ranked among the 100 best universities in the world. There are also many technical universities and engineering schools in Russia that enjoy a global reputation in their disciplines. We have found a high competitiveness level of Moscow and St. Petersburg universities. The international market for educational services does not give preference to universities with the status of a «national research» or «federal» (Endovitsky, Korotkikh, \& Voronova, 2020).

For Russian universities, the number of international students is one of the key indicators of internationalization...The article addresses the problems of language adaptation of foreign students who came from the former Soviet republics, mainly on the example of students from Turkmenistan (Belyakova, Sidorova, Petruneva \& Vasilyeva, 2020).

The International Organization of Russian Universities UK was created in order to promote the Belgorod State Research University, which was founded in 1876, worldwide. Over time, other renowned universities such as KFU, MAI, HSE, joined this Organization, reaching today the best universities in the entire Russian Federation (Russian-university, 2021).

A sample of 30 Russian universities, including participants in Project 5-100 and a control group of institutions with similar characteristics, was used. After joining the project, the participating universities increased both their cooperation with each other as well as with foreign universities and 
research institutions of the Russian Academy of Sciences, especially in the high-quality segment (Matveeva \& Ferligoj, 2020).

This study furthers the knowledge about the heterogeneous nature of entrepreneurialism at Russian universities and provides useful insights for policymaking and managerial practice (Budyldina, 2018).

One of the significant results of the study is an assessment of the dynamics of the average authors' productivity, which grows insignificantly and almost reached one article per author per year. This fact also shows that the growth of publication activity of top Russian universities is mainly associated with an increase in the number of faculty involved (Guskov, Kosyakov \& Selivanova, 2018).

The authors apply system analysis to study the existing realities of various aspects characterizing successfulness and opportunities to achieve academic leadership by leading Russian universities. This work maps out the existing visually perceived state of innovation ecosystems in some leading Russian universities (Petrosyants, Simonov, Mitrakhovich \& Iushkov, 2021).

The explained variance in the engagement in academic dishonesty equals $48 \%$ in the model for the full sample, and reaches $69 \%$ in the model for one of the considered institutions... This finding indicates a specific feature of Russian students' an ethical decision-making process discussed in the last part of the paper (Maloshonok \& Shmeleva, 2019).

For the first time, a three-stage sociological study was conducted involving 274 teachers and 215 students of Russian State Social University (RSSU) for 7 years (2009-2016)...The hypothesis was confirmed that changes in the social status of teachers are contradictory (Ilina, Oseev, Vinichenko, Kirillov, Kaurova \& Nakhratova, 2018).

\section{METHODOLOGY}

The research presents a qualitative-interpretative design, of a documentary type, which specified the selection procedure and the data recording (Barrero y Rosero, 2018).

In this research, 41 documents have been selected, carried out in the period 2016 - 2021; including: scientific articles, review articles and information from websites of recognized organizations. The keywords used in the searches were: Russian universities and COVID-19. For the selection of the documents, the following criteria were used: the year of publication, belonging to the research and being a reliable source. After reading each document, the data was entered into the bibliographic matrix, which is used to catalog the documents according to categories, which are presented in Table 1. 
Table 1. Bibliographic matrix

\begin{tabular}{|l|l|l|l|}
\hline Name & Type & Objectives & Conclusions \\
\hline & & & \\
\hline
\end{tabular}

Source: Adapted from Barrero \& Rosero (2018).

\section{RESULTS}

Figure 1. Education in the Russian Federation

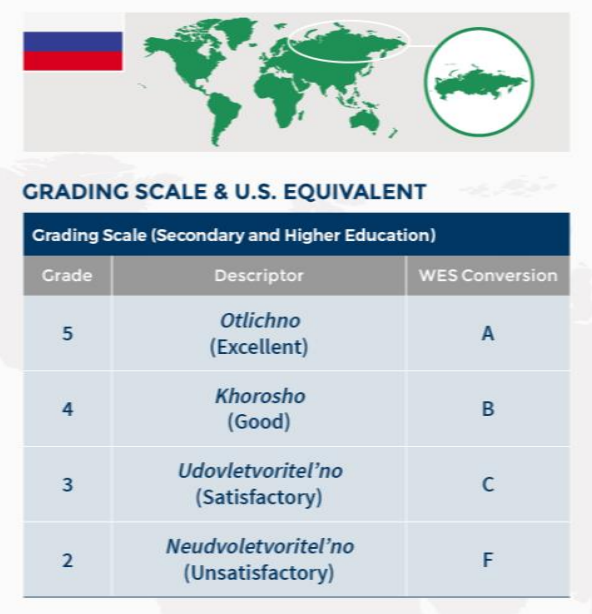

WES DOCUMENT REQUIREMENTS
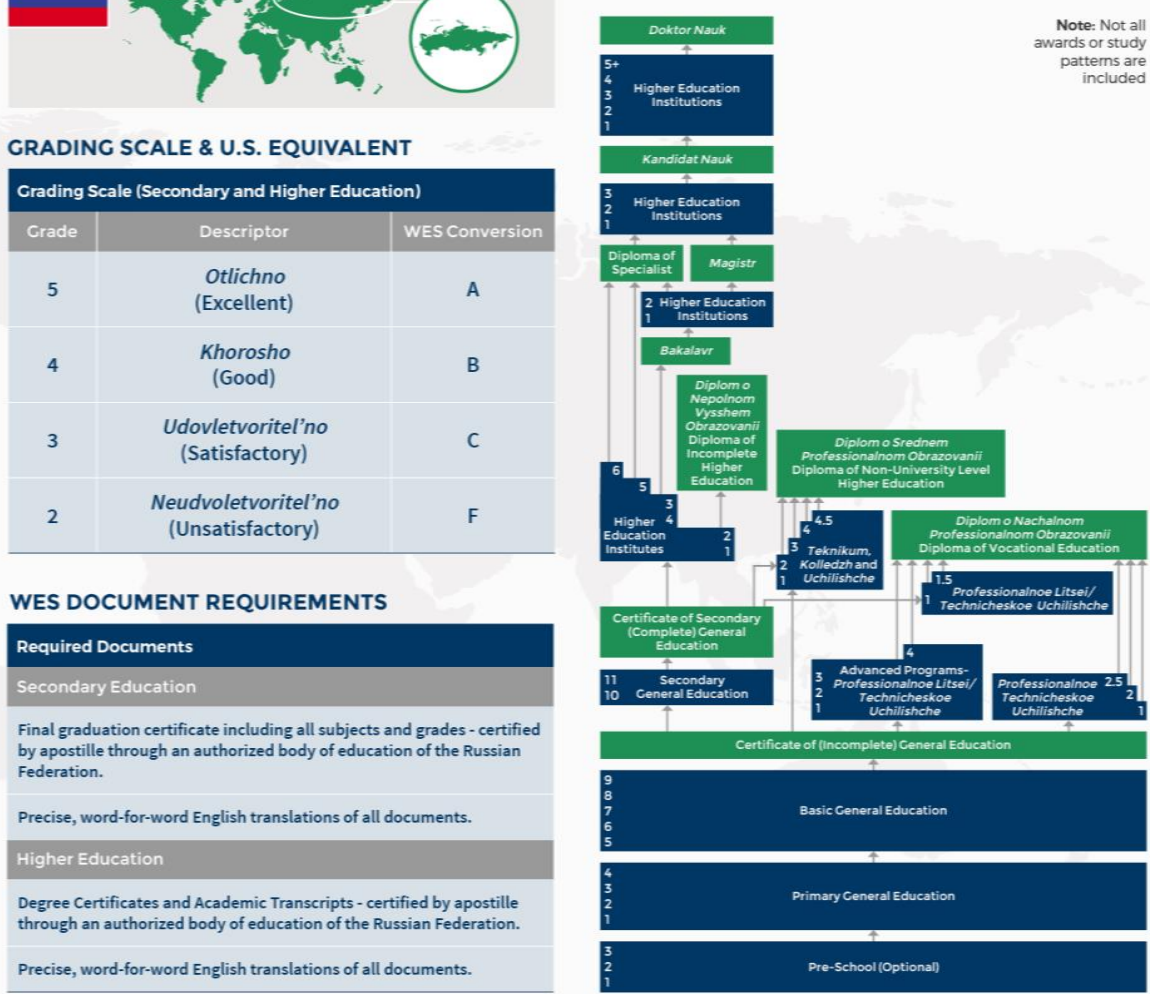

Source: Potapova (2017)

In figure 1, it was observed the equivalents of the Russian and the United States scale, the documents required at each educational level and the levels of the Russian educational system. 
Figure 2. Timeline of key higher education reforms in Russia, 1991-2015

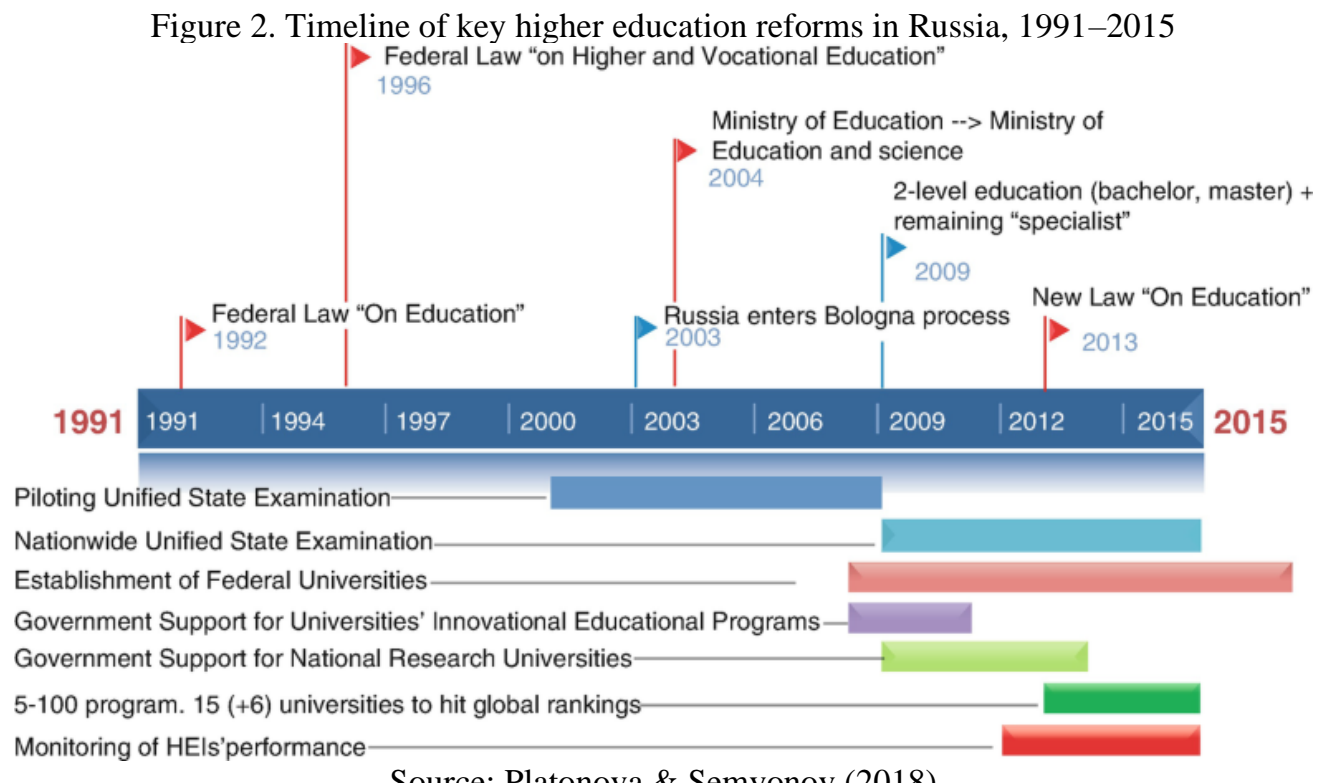

Source: Platonova \& Semyonov (2018).

In figure 2, the reforms of higher education in Russia were observed, in the period 1991 - 2015, with which it was sought to improve and modernize it. Although, more reforms are pending, especially to successfully face the current pandemic.

Figure 3. Number of students enrolled in higher education institutions in Russia from academic year 2014/2015 to 2018/2019, by degree (in 1,000s)

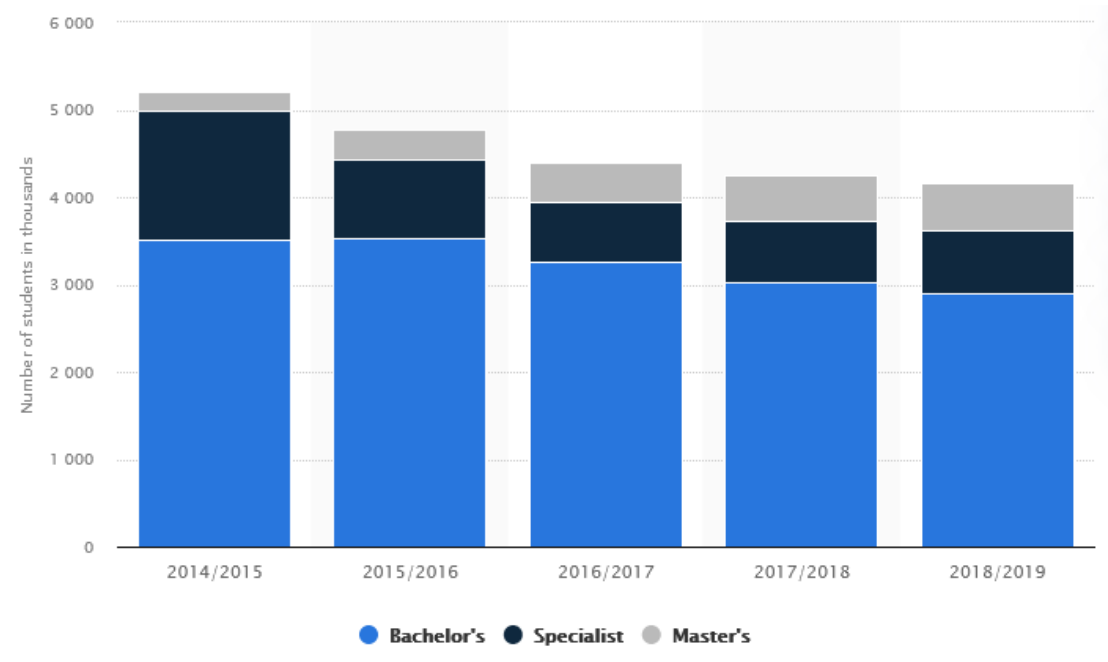

Source: Elagina (2020)

In figure 3, it was observed that the number of students enrolled in higher education institutions has decreased in the period from 2014/2015 to 2018/2019, due to various causes. 
Figure 4. Top universities in The Russian Federation

\begin{tabular}{|c|c|}
\hline University & Rank* \\
\hline Lomonosov Moscow State University & $=174^{\text {th }}$ \\
\hline $\begin{array}{l}\text { Moscow Institute of Physics and } \\
\text { Technology (MIPT) }\end{array}$ & $201-250^{\text {th }}$ \\
\hline HSE University & $251-300^{\text {th }}$ \\
\hline $\begin{array}{l}\text { Peter the Great St Petersburg } \\
\text { Polytechnic University }\end{array}$ & $301-350^{\text {th }}$ \\
\hline $\begin{array}{l}\text { Bauman Moscow State Technical } \\
\text { University }\end{array}$ & $401-500^{\text {th }}$ \\
\hline
\end{tabular}

In figure 4, it was observed that Lomonosov Moscow State University is the highest university located in the Times Higher Education 2021 ranking.

In addition, it is necessary to consider, The QS World University Rankings 2020 lists 48 Russian universities including MIREA - Russian Technological University...Also, on June 9, the tenth annual RAEX-100 ranking of the best universities in Russia for 2020 was published. MIREA - Russian Technological University improved its performance by four positions. In total, since 2018, it has risen by 21 points (MIREA, 2021).

\subsection{PROBLEMS}

The following problems in the research: (1) problems of transition to a structured model of doctoral education, (2) diffusion of doctoral education's goals, (3) unpreparedness of Russian universities for the massive expansion of $\mathrm{PhD}$ education, (4) ineffective mechanisms of doctoral student selection, (5) a lack of funding and a need for doctoral students to have paid work, (6) excessive dependence on supervisors and (7) insufficient study time and skills for meeting the requirement for publications before the date of defence (Maloshonok \& Terentev, 2019).

And the important overarching point is that Russian universities need to improve their collaboration with industry, and they need to develop new standards of administrative, research, and business activity that will promote innovation and entrepreneurship (Carayannis, Cherepovitsyn \& Ilinova, 2016).

The research showed that despite the potential of a learning management system to support both blended learning and e-learning, most e-learning initiatives are not fully realized; they completely or 
partially fail. Poor marketing strategies, poor service strategies and insufficient technical support are some of the most likely causes of failure (Vershitskaya, Mikhaylova, Gilmanshina et al., 2020).

The object of the study was the State University of Management and the Financial University under the Government of the Russian Federation. After examination of the current state of university digitalization, we have identified major problems which become an obstacle during digital transformation (Rozhkova, Rozhkova, Blinova, 2020).

Longitudinal research shows that in Russia English language teaching has several problems which exist throughout decades. This article focuses on some of them: class interaction mode; the use of native (Russian) language in class; error correction strategies employed by teachers (Rasskazova, Guzikova \& Green, 2017).

Based on the results of a cross-institutional online-survey of doctoral students $(\mathrm{N}=2,034)$ conducted in 16 leading Russian universities, three main barriers to the completion of doctoral programs were distinguished: (1) poor supervision, (2) lack of financing and forced need to have a paid job, (3) tough requirements and a lack of competences to fulfill them (Terentev, Bekova \& Maloshonok, 2021).

Scientists and academics in Russia are protesting against a proposed law change that they say will damage academic freedom and free speech. The amendment to Russia's law on education, which lawmakers say is intended to stop anti-Russian propaganda, would require academics and educators to get permission from state authorities to do public outreach for educational activities, including those involving science (Schiermeier, 2021).

\subsection{COVID-19}

In Russia, universities closed in March when President Vladimir Putin announced a series of mandatory non-work days in the country. Since then, distance learning has been implemented, and college entrance exams were moved to a virtual format (Pardini, 2020).

The first challenge was the urgent need to switch to online teaching. There are 429 educational programmes at RUDN University, including medical and engineering courses... The second challenge was organising campus life during the pandemic. Of the 9,000 students who live on the RUDN campus, almost 7,000 decided to stay in dormitories (Council of Europe Portal, 2021).

Russia has become the first country to have completed clinical trials of a Covid-19 vaccine candidate, after Sechenov University said that it had concluded its study...data showed the vaccine candidate's effectiveness, reported Russian news agency TASS (Clinical Trials Arena, 2020).

More than 100 universities have provided jobs for students who have lost their income due to the pandemic. For instance, Tomsk University has announced 200 available positions for students. The 
Ministry of Education will support those universities that are organizing student employment programs (The World Bank Group, 2020).

Now, universities in Russia have the legal right to demand a COVID vaccination certificate (or a medical exemption) when they house students in their dorms. The decision was announced last week by the Ministry of Education and Science (HSE University, 2021).

We spoke to international students at the National University of Science and Technology MISIS (NUST MISIS) to find out how lockdown has affected their studies. 20,000 students are enrolled at NUST MISIS and a quarter of them come to the university from abroad. As the pandemic spread, not everyone was able or willing to go home (Craig, 2020).

We remind you of the need for an advance warning of the Ural Federal University (UrFU International Students Adaptation Center) 10 days before arrival about your arrival. When processing documents at the UrFU International Students Adaptation Center, you can issue a medical insurance policy, which includes the cost of the SARS-CoV-2 test (Ural Federal University, 2021).

The Government will allocate a total of almost 8.5 billion roubles to the regions to cover vacation benefits and compensation for unused vacations for medical staff, as well as social workers. Everyone who was eligible for incentive payments last year will receive them (Government House, 2021).

\subsection{EFFORTS}

In the Post-Soviet period, Russian higher education has tremendously expanded. The dramatic growth of the number of students and institutions has been facilitated by the introduction of tuition fees in public and a new private sector (Platonova \& Semyonov, 2018).

Moscow State University, the first Russian University founded in 1755 on the initiative of Mikhail Lomonosov, an outstanding scientist of the Enlightenment, whose unsettled encyclopedic mind and energy gave the inner impetus to the project... Today, the emphasis is on advancing the applied science: new materials, genetics, biomedicine, pharmaceutics, cognitive sciences, ecology, and information technologies (MSU, 2021).

Students of the Innopolis University get modern education and take on independent research projects in the sphere of IT and robotics. At the end of their studies, students implement an industrial project, that is counted toward a thesis (Innopolis, 2020).

RUDN University offers any specialization e.g. technical, scientific, medical, economic, humanitarian one. In RUDN University an ambitious student has an opportunity to become a theoretically and practically advanced specialist (RUDN University, 2021). 
We estimate the effects of the Russian University excellence program (Project 5-100) initiated by the Government in 2013 (Project 5-100) on the research performance of those leading Russian universities that received, on the competitive basis, substantial financial support within this program (Poldin, Matveeva, Sterligov \& Yudkevich, 2017).

Nizhnevartovsk State University has held Student Research Competition among Russian educational institutions. It aimed to attract students to research activities and studying environment and climate change impact on the human health in Russia and EU countries. All works of participants were revised by experts (Nizhnevartovsk State University, 2021).

The experiment involves the students and professors of the Ammosov North-Eastern Federal University (NEFU), the Herzen State Pedagogical University of Russia (RSPU) and Chelyabinsk State University $(\mathrm{CSU}) \ldots$ The results of the study prove the necessity to develop educational and methodological materials for the implementation of new form of training in NEFU, RSPU and CSU (Barakhsanova, Vlasova, Alekseeva, Kuzin \& Zhukov (2020).

For over 120 years, the Russian University of Transport (MIIT) has evolved from small engineering school into a multidisciplinary and practice-oriented university, which implements its strategy in close cooperation with industrial partners and global education leaders (Klimov, 2021).

\section{CONCLUSIONS}

For Russian universities, the number of international students is a great indicator of internationalization.

Russian universities need to improve their collaboration with industry. Universities closed in March of 2020, during the pandemic.

An important number of universities have provided jobs for students who need help. The most important institution is Lomonosov Moscow State University (MSU).

Russian universities are gradually achieving a better position in the world rankings, for this it is important to continue with their process of internationalization and investment in infrastructure. 


\section{BIBLIOGRAPHIC REFERENCES}

Avanesova, A.A., Shamliyan, T.A. (2018). Comparative trends in research performance of the Russian universities. Scientometrics 116, 2019-2052. https://doi.org/10.1007/s11192-018-2807-6

Barakhsanova, E., Vlasova, E., Alekseeva, G., Kuzin, Z., \& Zhukov, N. (2020). Characteristics of Implementation of Distance Remote Access to Learning in Russian Universities. Propósitos y Representaciones, 8(SPE3), e701. doi:http://dx.doi.org/10.20511/pyr2020.v8nSPE3.701

Barrero, A. \& Rosero, A. (2018). Estado del Arte sobre Concepciones de la Diversidad en el Contexto Escolar Infantil. Revista Latinoamericana de Educación Inclusiva, 2018, 12(1), 39-55 https://doi.org/10.4067/S0718-73782018000100004

Belyakova, L. F., Sidorova, T. L., Petruneva, R. M. \& Vasilyeva, V. D. (2020). Vysshee Obrazovanie v Rossii = Higher Education in Russia, № 4, p. 127-135. Vysshee Obrazovanie $\mathrm{v}$ Rossii $=$ Higher Education in Russia, 2020, № 4, p. 127-135

Budyldina, N. (2018). Entrepreneurial universities and regional contribution. Int Entrep Manag J 14, $265-$ 277. https://doi.org/10.1007/s11365-018-0500-0

Carayannis, E.G., Cherepovitsyn, A.Y. \& Ilinova, A.A. (2016). Technology commercialization in entrepreneurial universities: the US and Russian experience. J Technol Transf 41, 1135-1147. https://doi.org/10.1007/s10961-015-9406-y

Clinical Trials Arena (2020). Russian university completes clinical trials of Covid-19 vaccine. Retrieved from https://www.clinicaltrialsarena.com/news/russia-completes-covid19-vaccine-trial/

Council of Europe Portal (2021). Interview with Prof. Vladimir Filippov, President of Peoples' Friendship University of Russia (RUDN), Doctor of Physical and Mathematical Sciences. Retrieved from https://www.coe.int/en/web/education/interview-with-vladimir-filippov-rudn\#\{\%2266944180\%22:[0]\}

Craig, O. (2020). Lockdown in Russia: How Is It Affecting International Students?. Retrieved from https://www.topuniversities.com/where-to-study/europe/russia/lockdown-russia-how-it-affectinginternational-students

Elagina, D. (2020). Number of university students in Russia 2014-2019, by degree. Retrieved from https://www.statista.com/statistics/1130168/number-of-students-in-universities-by-degree-russia/

Endovitsky, D.A., Korotkikh, V.V. \& Voronova, M.V. (2020). Competitiveness of Russian Universities in the Global System of Higher Education: Quantitative Analysis. Vysshee obrazovanie v Rossii = Higher Education in Russia. Vol. 29, no. 2, pp. 9-26. DOI: https://doi.org/10.31992/0869-3617-2020-29-2-9-26

Government House (2021). Meeting of the Presidium of the Government Coordinating Council to control the incidence of the novel coronavirus infection in Russia. Retrieved from http://government.ru/en/news/42642/

Guskov, A.E., Kosyakov, D.V. \& Selivanova, I.V. (2018). Boosting research productivity in top Russian universities: the circumstances of breakthrough. Scientometrics 117, 1053-1080. https://doi.org/10.1007/s11192-018-2890-8 
HSE University (2021). Universities Are Now Legally Allowed to Deny Dorms to Unvaccinated Students. How it will work at HSE University. Retrieved from https://www.hse.ru/en/our/news/482117302.html

Ilina, I., Oseev, A., Vinichenko, M., Kirillov, A., Kaurova, O. \& Nakhratova, E. (2018). Transformation of Social Status of Teachers of Russian Universities. Modern Journal of Language Teaching Methods. Retrieved from https://www.elibrary.ru/item.asp?id=36852127

Innopolis (2020). About University. Education, research and development in the field of IT and Robotics. Retrieved from https://innopolis.university/en/about/

Klimov, A. (2021). Russian University Of Transport (MIIT). Retrieved from https://www.miit.ru/en Maloshonok, N. \& Terentev, E. (2019). National barriers to the completion of doctoral programs at Russian universities. High Educ 77, 195-211. https://doi.org/10.1007/s10734-018-0267-9

Maloshonok, N. \& Shmeleva, E. (2019). Factors Influencing Academic Dishonesty among Undergraduate Students at Russian Universities. J Acad Ethics 17, 313-329. https://doi.org/10.1007/s10805-019-9324-y

Matveeva, N. \& Ferligoj, A. (2020). Scientific collaboration in Russian universities before and after the excellence initiative Project 5-100. Scientometrics 124, 2383-2407. https://doi.org/10.1007/s11192-02003602-6

MIREA (2021). MIREA - Russian Technological University was included into the overall QS World University Rankings for the first time and improved its position in the RAEX-100. Retrieved from https://english.mirea.ru/news/mirea-russian-technological-university-was-included-into-the-overall-qsworld-university-rankings-fo/

MSU (2021). Lomonosov Moscow State University. Retrieved from https://www.msu.ru/en/

Nizhnevartovsk State University (2021). Research Competition at Nizhnevartovsk State University. Retrieved from http://en.nvsu.ru/

Pardini, V. (2020). Russia's Higher Education System During the Coronavirus Pandemic: Fault Lines Exposed Even as Classes Begin. Retrieved from https://www.wilsoncenter.org/blog-post/russias-highereducation-system-during-coronavirus-pandemic-fault-lines-exposed-even

Petrosyants, D., Simonov, K., Mitrakhovich, S. \& Iushkov, I. (2021). Foresight for development of innovation ecosystems in Russian education: information basis of evaluation. SHS Web of Conferences, p. 02013. https://doi.org/10.1051/shsconf/202110302013

Poldin, O., Matveeva, N., Sterligov, I., \& Yudkevich, M. (2017). Publication Activities of Russian Universities: The Effects of Project 5-100. Educational Studies, Higher School of Economics, issue 2, pages 5-100.

Potapova, E. \& Trines, S. (2017). Education in the Russian Federation. Retrieved from https://wenr.wes.org/2017/06/education-in-the-russian-federation

Platonova D. \& Semyonov D. (2018). Russia: The Institutional Landscape of Russian Higher Education. In: Huisman J., Smolentseva A., Froumin I. (eds) 25 Years of Transformations of Higher Education Systems in Post-Soviet Countries. Palgrave Studies in Global Higher Education. Palgrave Macmillan, Cham. https://doi.org/10.1007/978-3-319-52980-6_13 
Rasskazova, T., Guzikova, M. \& Green, A. (2017). English language teacher development in a Russian university: Context, problems and implications. Ampersand, Volume 4, Pages 1-9. https://doi.org/10.1016/j.amper.2017.01.001.

Rodionov, D.; Fersman, N. \& Kushneva, O. (2016). International Journal of Environmental and Science Education, v11 n8 p2207-2222

Rozhkova D., Rozhkova N., Blinova U. (2020). Digital Universities in Russia: Prospects and Problems. In: Antipova T., Rocha Á. (eds) Digital Science 2019. DSIC 2019. Advances in Intelligent Systems nd Computing, vol 1114. Springer, Cham. https://doi.org/10.1007/978-3-030-37737-3_23

RUDN University (2021). In RUDN University you can. Retrieved from https://eng.rudn.ru/

Russian University (2021). Sobre Nosotros. Retrieved from https://www.russian-university.com/

Schiermeier, Q. (2021). Russian academics decry law change that threatens scientific outreach. Retrieved from https://www.nature.com/articles/d41586-021-00385-5

Study in Russia (2021). Universities in Russia. Retrieved from https://studyinrussia.ru/en/study-inrussia/universities/

Study.eu (2021). Rankings: The 51 best universities in Russia for 2021/2022. Retrieved from https://www.study.eu/best-universities/russia

Terentev, E., Bekova, S., \& Maloshonok, N. (2021). Three challenges to Russian system of doctoral education: Why only one out of ten doctoral students defends thesis? International Journal of Chinese Education. https://doi.org/10.1177/22125868211007016

The World Bank Group (2020). COVID-19 (Coronavirus) Policy Response to Addressing Learning Gaps and Inequalities in Russia. Retrieved from https://www.worldbank.org/en/country/russia/brief/covid-19response-learning-gaps-inequalities-russia

Timeshighereducation (2021). Top universities in The Russian Federation. Retrieved from https://www.timeshighereducation.com/student/where-to-study/study-in-russian-federation

Ural Federal University (2021). COVID-19 Containment. Retrieved from https://urfu.ru/en/covid-19containment/

Vershitskaya, E.R., Mikhaylova, A.V., Gilmanshina, S.I. et al. (2020). Present-day management of universities in Russia: Prospects and challenges of e-learning. Educ Inf Technol 25, 611-621. https://doi.org/10.1007/s10639-019-09978-0 